\title{
Stratigraphic evidence in the ancient urban walls of Cagliari (Sardinia, Italy)
}

\author{
D. R. Fiorino \\ Department of Civil-Environmental Engineering and Architecture \\ (DICAAR), University of Cagliari, Italy
}

\begin{abstract}
The research focuses mainly on the extraordinary stratigraphy still evident in the ancient urban walls of Cagliari (Sardinia-Italy).

The overall interest of this study lies in the fact that it provides a substantial contribution to the definition of a methodology for the study of the growth and transformation of walled cities. The first objective achieved refers to chronostratigraphy and is the experimentation of a methodology capable of dating bricks and stone masonries and the definition of the relative and absolute chronology of structures. More specifically, by means of an archaeological survey, each architectural stratum has been measured and described in relation to its building materials, state of conservation, stratigraphic relationships, also using the Harris matrix. Furthermore, great effort has gone into documenting those parts of the walls that are still authentic, as recent works carried out on consistent portions of these structures have cancelled some relevant stratifications, particularly those referred to historical restoration works. Regarding the tools used, all data has been stored implementing a web-based database (SICaR) developed by the Italian Ministry of Cultural Heritage (MIBAC).
\end{abstract}

Keywords: urban walls, urban stratigraphy, chronotypologies, masonries, restoration.

\section{Origin and evolution of the urban walls in Cagliari}

The existence of a fortified nucleus in the city of Cagliari was first mentioned in 1217 , with reference to today's quarter of Castello - indicated in various documents with the name Mons de Castro or also Castel di Castro - founded by 
the Pisans on the hill which had probably housed the castrum of the Roman Carales, behind the pre-existing port settlement of Bagnaria.

Once the town of Santa Igia was destroyed and the Giudicato of Cagliari was overthrown, as of 1257 the citadel was expanded by the Pisans by creating the two appendixes of Villanova and Stampace, built at the same time following a unitary plan, which can be connected to the structure used in those same years for the foundation of the Tuscan "terre murate", whose layout reminds us of the iconography of a golden eagle with a cross on its chest, recurrent in medieval proimperial cities such as Pisa (Cadinu [1]). The primitive Pisan wall system was then strengthened and modified over the centuries in response to the new weapons used and the resulting defence techniques, making Cagliari one of the safest military and commercial bases in the Mediterranean, until the fortified town was decommissioned.

In 1323, the Aragonese started to modernise the primitive Pisan curtain walls, characterised by the imposing towers of San Pancrazio (1305), of the Elephant (1307), of the Lion and Santa Lucia, but the real changes took place in the first half of the $16^{\text {th }}$ century, after pieces of ordnance were introduced. In order to strengthen the north-western sector of the city, which could be easily attacked because of the land morphology, viceroy Joan Dusay created two new bastions, widely criticised from a technical-operational point of view, one in the area of San Pancrazio (1501-1503) and one in the area of Santa Croce.

The arrival in Sardinia of engineer Rocco Capellino from Cremona(1552-1572), first, and of engineers Jacopo and Giorgio Paleari Fratino from Ticino (15631578), later, along with other expert technicians such as Alessandro Febo and Giovam Battista Cairati, led to the introduction of high-level "modern" architectural and military solutions in the defensive system of the main fortified city in Sardinia, consistent with the time's most updated essays, which reveal an accurate study of the local morphology and a wise use of local building materials. In particular, the Palearis introduced substantial changes to San Pancrazio's tenaille line, to the shape of the bastion of Santa Croce and to the entire western front of the Castle, for a better "correspondence" between artilleries (Pirinu [2]).

From 1720 to the Italian Unification, the annexation of Sardinia to the Savoy territories entailed a new season of transformations to the fortified city of Cagliari, interventions which were planned and carried out by engineers belonging to the Royal Unit of Military Engineering (Antonio Felice De Vincenti, Augusto La Vallèe, Carlo Barabino), mainly in the north-western part of the city (area of the Royal Arsenal, the Citadel of Buoncammino, the Bastion of San Filippo). These include the creation of the Porta d'Apremont, finished in 1741 and demolished in 1914 to allow the passage of the tram line.

The decommissioning of the military stronghold, which took place in 1866, marked the legitimation of significant demolitions of bastions and walls, considered an obstacle to the hoped-for expansion and modernisation of the city. Only in 1902 will the monumental character of the curtain walls and defence towers in Cagliari be acknowledged by the enlightened personality of engineer Dionigi Scano, creator and promoter of a brave campaign of philological renovations and restorations aimed at freeing the Pisan towers and wall curtains, 
marking a particular moment in the history of restoration in Sardinia. Finally, the interventions by Libero Cecchini and Piero Gazzola to reconvert the areas of the Royal Arsenal into the Citadel of Museums (Gazzola and Cecchini [3]) date back to $1957-1979$.

\section{A methodology for the study of ancient city walls as stratigraphic evidence of urban development}

The walled city, with its wall palimpsest, its stratified urban texture and the formalarchitectural identity of the intramural structures, still represents a transversal document of the history of architecture - not only military - and the history of restoration, with an undoubted international importance fig. 1 .

Based on this awareness, a systematic scientific study of the curtain walls started in 2013. The need to document those parts of the walls that are still authentic also derives from the fact that recent works carried out on consistent portions of these structures have already cancelled some considerable stratifications, particularly those referred to historical restoration works. Further planned interventions threaten the conservation of other parts of the city walls.

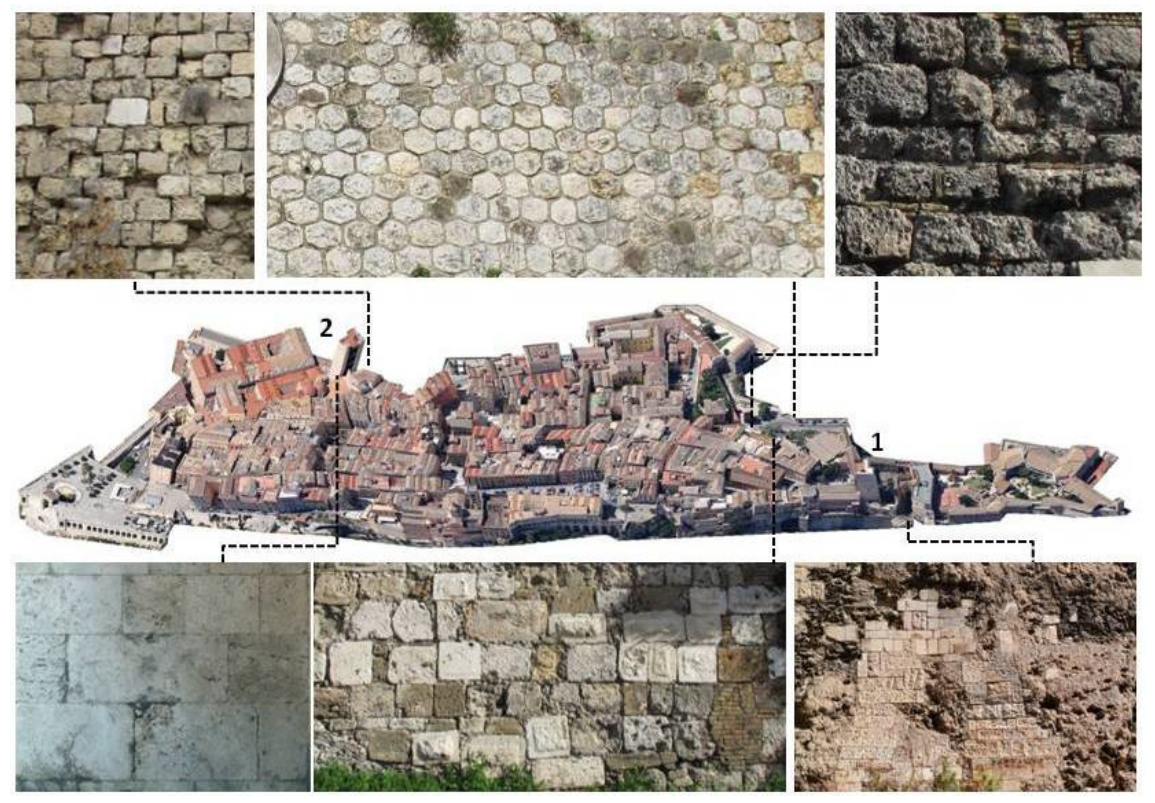

Figure 1: Wall palimpsest of the ancient quarter of Castello: 1) San Pancrazio area; 2) Elephant tower.

The research, currently in progress, includes the following activities: photogrammetric surveys of the wall curtains; analysis of the facades by characterising the building materials and identifying the historical quarries of 
origin; dimensional analysis of the constitutive elements and the related working techniques; analysis of the units and stratigraphic relationships in order to define relative chronologies; documentary comparisons between the sources and the monument for the absolute dating of the different wall sections; assessment of the state of conservation and of the intrinsic, extrinsic and recurring pathologies; definition of the material and anthropic vulnerability of the wall patrimony; identification of sustainable intervention criteria.

The first phase of the research involved the reorganisation of the many historical sources. In particular, the evolution of scientific production has led the currently available bibliographical sources to suggest different and sometimes antithetical historical interpretations and reconstruction hypotheses, depending on when they were formulated. This is why direct access to archival sources is often necessary in order to carry out a personal in-depth disciplinary or thematic analysis. Thus the need for a systematic computerisation and transcription, in order to create a virtual archive capable of concentrating the main material contained in different archives and collections, making consultation and cross-referencing easier and providing, when possible, a georeferentiation of the related content.

The examination of the studies on archival sources has led to the awareness of the lack of specific studies on restoration activities carried out on the defence structures in Cagliari from 1866, when the city was no longer used as a military stronghold. It was an important moment for the conservation of these artefacts since, after a first and well-documented transformation phase of the bastions into urban boulevards, from the early $20^{\text {th }}$ century important restoration campaigns started, carried out by local safeguard offices, causing a great loss of historical stratifications due to huge operations aimed at a philological liberation and reinstatement. The ideal return to the primitive Pisan structure is fully consistent with the nationalist urgencies of the beginning of the century, which characterised the contemporary Italian and European operational practice. The approach to the wall palimpsest then changed during the $20^{\text {th }}$ century, never becoming truly aware of the importance of the multi-stratified walls as a unitary monument, a position which has appeared in the scientific production only recently (Cadinu [4]) and that has yet to be accepted by urban development strategies. The overall attitude often remains exclusively that of the planning "excuse" rather than of a mature overall vision of the possible transformations.

A change in the perspective in this sense can only come from the correct acknowledgement of the role of urban stratigraphy, in the knowledge and transformation process of the historical city (Fiorino [5]).

One of the goals of this research is to prove the centrality of the study of the wall palimpsests of the defensive system in order to understand the evolution of the historical city as a whole. In fact, the in-depth stratigraphic analyses carried out so far have allowed to open the research field to extraordinary material and typological correspondences with other historical urban artefacts and, in particular, with the wall stratifications of great religious complexes, not only in Cagliari. Combining material and metric data provided by the first case studies, there is a frequent correspondence between the building techniques used to build defensive walls and those found in wall bays of bell towers and large religious 
buildings. The impact of this correspondence is not limited to a local level, but has significant comparisons in coeval Spanish and Italian buildings, proving the existence of codified building models and the extra-local circulation of workers active in Sardinia, coming from educated environments and technically updated, which represented an opportunity for the local workforce to be trained and keep up with new techniques.

Construction sites of walls and religious buildings were therefore meant to be places dedicated to a constructive experimentation process and the transmission of knowledge, to the point that we can today use the recurring building techniques as dating balks also for buildings or parts of them which cannot be dated directly using archival documents.

Although this is only the initial and in some ways intuitive phase of the research, there are at least two types of walls examining which we can foresee the potential of an extensive research.

The first one is the regular-sized, bossed ashlar masonry in pietra forte, present in several portions of the walls, including the part at the foot of the towers of San Pancrazio (1305) and the Elephant (1307). A similar formal selection can be found, at a local level, on the base of the bell tower in the Church of San Giacomo (1438-1442), but also in some building models of eastern Spain, including the bell tower of the Cathedral in Tarragona (1332). The dating of the bell tower structure in San Giacomo, which is possible thanks to reliable archival sources, and the rigorous correspondence with the above-mentioned technique in Tarragona, lead us to associate this building technique with the Spanish-Aragonese period rather than the Pisan one. The bossage at the foot of the two towers built by the Pisans therefore leads to hypothesise that the base was re-wrapped following its initial installation, maybe because of the lowering of the ground level below the walled perimeter, fig. 2 .

Another significant case in order to test the applicability of the method is that of the internal walls of the Pisan towers. It is a regular-sized masonry consisting of squared ashlars in pietra forte, smoothed on the surface. Again, the analogies can be related to two bell towers already ascribed to the Pisan historical-cultural context: the one of the Cathedral of Cagliari dedicated to Santa Cecilia and the one of the Cathedral of Sassari dedicated to San Nicola fig. 3a)-c). The possibility of associating this masonry technique to a recurring chronotypology referred to a period of time between the $13^{\text {th }}$ and the beginning of the $14^{\text {th }}$ century leads to dating perspectives for other wall structures of the same urban context, for which no specific archival data was available, as, for example, the tank recently found inside the cloister of the convent of Santa Chiara in the ancient Cagliari quarter of Stampace (fig. 3d). It is a rectangular well, covered by a vaulted structure with a double access to draw the water. The well shaft is lined with good quality masonry in pietra forte ashlars set on a bed of regular joints on very thin mortar. The accuracy of this wall face could date the structure to the same Pisan period, offering new survey perspectives both for the history of the religious complex and the urban evolution of this part of the historical city.

Other structures adjacent to the Santa Chiara complex, yet to be studied, give life to a picture of remains whose stratigraphic analysis might lead to new research 
scenarios. One is the retaining wall of the area limiting the courtyard of the former convent, and slightly to the north, the morphology of a block reproducing the typical shape of bastioned embankments, showed in fig. 4, elements which lead us to hypothesise a significant stratification of urban archaeology that has yet to be investigated.
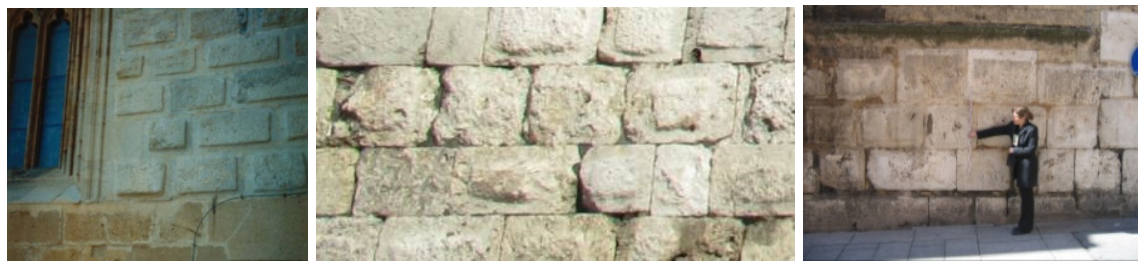

Figure 2: Comparison between defensive walls and bell tower walls from the Spanish period (15 $\left.5^{\text {th }} \mathrm{sec}.\right)$ : a) Tarragona Cathedral; b) Cagliari urban wall; c) San Giacomo bell tower (Cagliari).
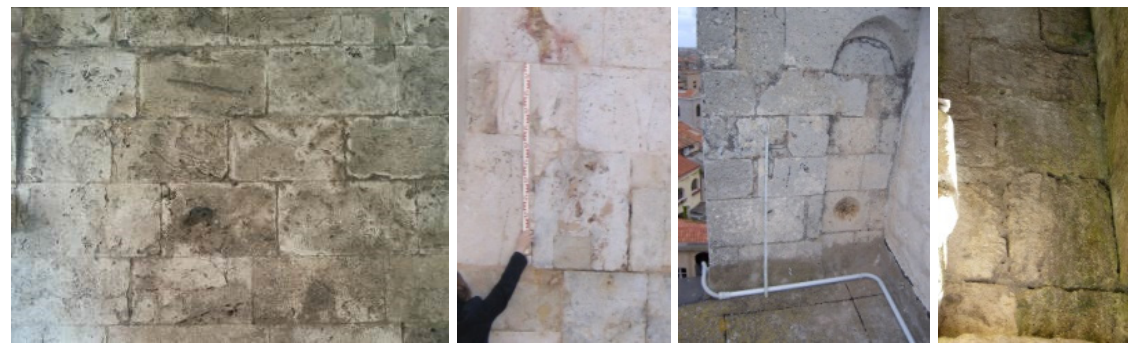

Figure 3: Comparison between defensive walls and bell tower walls from the Pisan period (13 ${ }^{\text {th }}$ sec.): a-b) Cagliari, Elephant Tower and Santa Cecilia Cathedral; c) Sassari, San Nicola Cathedral, d) Cagliari, tank from the former convent of Santa Chiara.
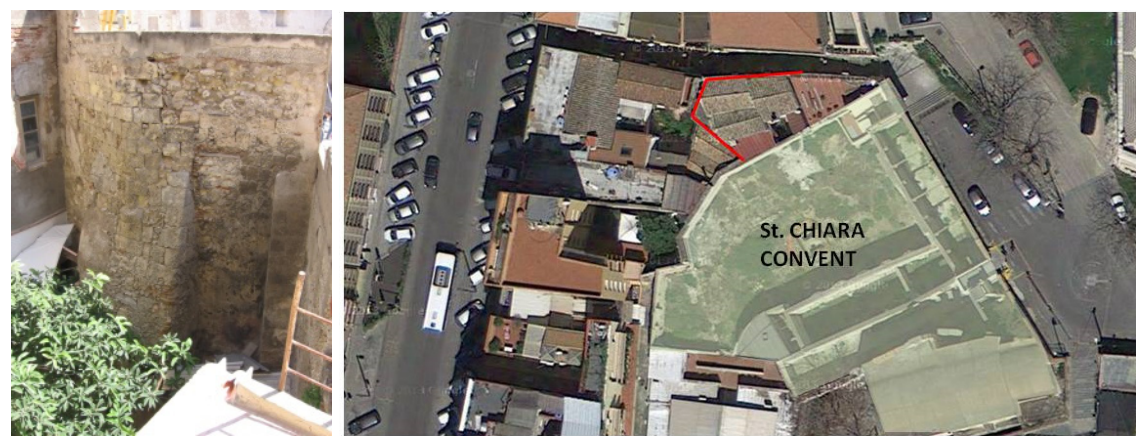

Figure 4: Typical shape of bastioned embankments close to Santa Chiara Convent. 
The crucial element in carrying out the research, in order for the proposed methodology to produce results which are scientifically rigorous and reliable, is represented by the choice of the balks. We believe the walled system represents to this purpose an incredible mosaic of stratigraphic tiles which decoded can factually increase the keys to interpret local history.

A further strong point of the thesis supported is the fact that it is widely documented that in the past religious orders used pre-existing structures as a foundation for their buildings, both for static and economic reasons. The old wall patterns were for this purpose an invaluable opportunity, representing a stable basis for religious buildings, as attested for the Church of Santa Croce in Castello, built by the Jesuit Fathers (Fiorino [6]), for the complex of San Giuseppe degli Scolopi (Mattana and Schirru [7]) and has been hypothesised for the complex of San Domenico in Villanova (Giammusso [8]).

Considering the extent of the outlined research, it is obvious that it cannot be the result of the work of one researcher, but the product of the stratification of knowledge obtained over time, with the multidisciplinary contribution of several work groups. This stratification will only be possible using a multi-access information system, updated constantly, where all the information coming from all the research channels can merge, piece after piece, information which will then be compared and interpreted cross-checking the data using thematic approaches oriented to different finalities, be it study, preservation or restoration. The historical city, in fact, is not a mere object crystallised in time, meant to be preserved as it is, but a dynamic monument which is constantly changing. Therefore, the goal of the research is to optimise the knowledge of its past phases, contextualise them and understand the reciprocal relations in order to monitor and manage the transformations according to a process which is aware and respectful of what is pre-existing.

It is more of a virtuous analysis, documentation and interpretation process, representing at the same time an essential working tool for whoever operates in the stratified urban context, rather than a concrete fact-finding goal. For this reason, the methodology has been tested within the university teaching methods, thanks to an agreement between the Department of Civil-Environmental Engineering and Architecture and the Educational Services of the Superintendency for the Architectural and Landscape Heritage (BAPSAE) of Cagliari and Oristano Two restoration workshops and some graduation theses were carried out within this agreement.

\section{The case of the area of San Pancrazio as a study model}

The study integrated between research and teaching started from the area of the Tower of San Pancrazio, which was the northern entrance to the city and has always represented the most vulnerable part since it opened directly onto the hinterland. This is why it is one of the most stratified portions of the city walls, from the Pisan period to the crucial nineteenth-century restorations.

The work started with the photogrammetric survey shown in Fig. 5, and the graphic restitution of the wall face. As shown in Fig. 6, great attention was given 


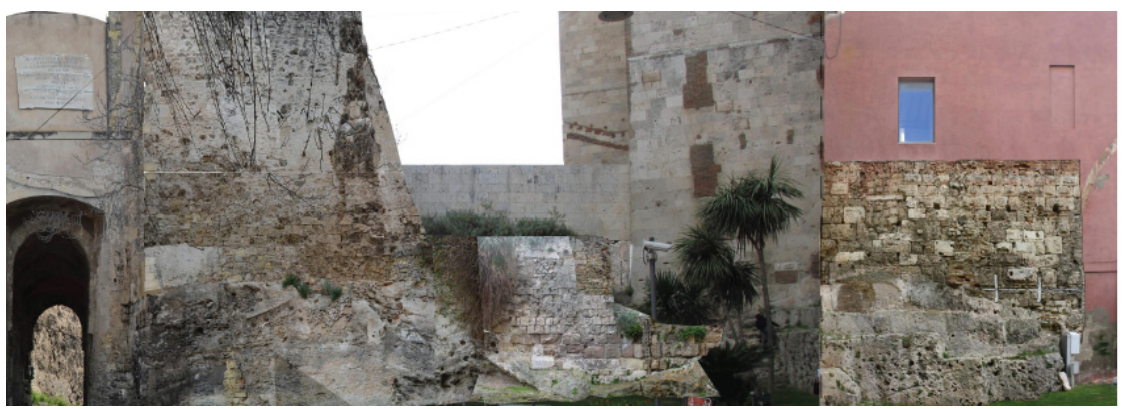

Figure 5: Photogrammetric survey.

to drawing the single ashlars, as the detailed graphic reproduction of the wall texture typical of archaeological surveys can help in becoming aware of the material consistency of the artefact, of its metric and material discontinuity, and therefore in understanding its building nature.

The survey clearly shows traces of the prisons built starting in 1762 in the tower courtyard, near the wall curtain, demolished in 1902 following the project of the Regional Office for the Preservation of Monuments, activities documented in the Archive of the BAPSAE Superintendency of Cagliari and Oristano, where the photograph in fig. 6 is stored.

On the basis of the metric survey thus conducted, the stratigraphic units represented by walls (USM) and those represented by the coatings (UR) were identified, and 14 wall types were classified, with a selection shown in fig. 7 . The synthesis of the stratigraphic relations and the building of the Harris matrix have allowed us to identify seven sequential phases, illustrated in fig. 8, within a very wide time frame $\left(12^{\text {th }}-20^{\text {th }}\right.$ centuries) (Fiorino [9]). (Figures 5-8 are taken from the final papers by students F. Fiori, L. Porcella, C. Virdis, with the support of tutors E. Pilia e G. Tomasi, supervised by the lecturer.)

In this phase, as we wait for the authorisations to collect the samples, it was not possible to carry out instrumental surveys on the stone material and mortars. However, a diagnostic survey has been planned so as to characterise the lithotypes and locate the historical quarries they come from, in order to obtain precise building dates or possible reuse procedures. The study of this part of the urban walls will also have to be completed with the analysis of the wall faces of the adjacent Dusay bastion and the revision and comparative updating of a stratigraphic survey carried out by the above-mentioned Mattana and Schirru on the wall faces opposite the curtain examined, which can be referred to the seawall of the first Pisan structure, which underwent great changes during the following centuries.

The entire analysis carried out was documented and registered in the SICaR/web system, produced and managed by the Ministry of Cultural Heritage and Activities and Tourism.

SICAR w/b is an open source webGIS designed to integrate, store, edit, manipulate, analyse, manage, share and display all types of data gathered during restoration analyses and interventions. All the heterogeneous data can be mapped 
and geo-referenced to 2D models, since the system is able to merge cartography, statistical analysis and database technology.

The use of the SICaR/web system allows us to implement the documentary content over time, update it, consult it via web, cross-check data for thematic interpretations, letting people at different levels operate on the system simultaneously. Fig. 9 shows the mapping of the erosion with the alveolisation in the pietra forte ashlars in one of the wall sections which were studied.
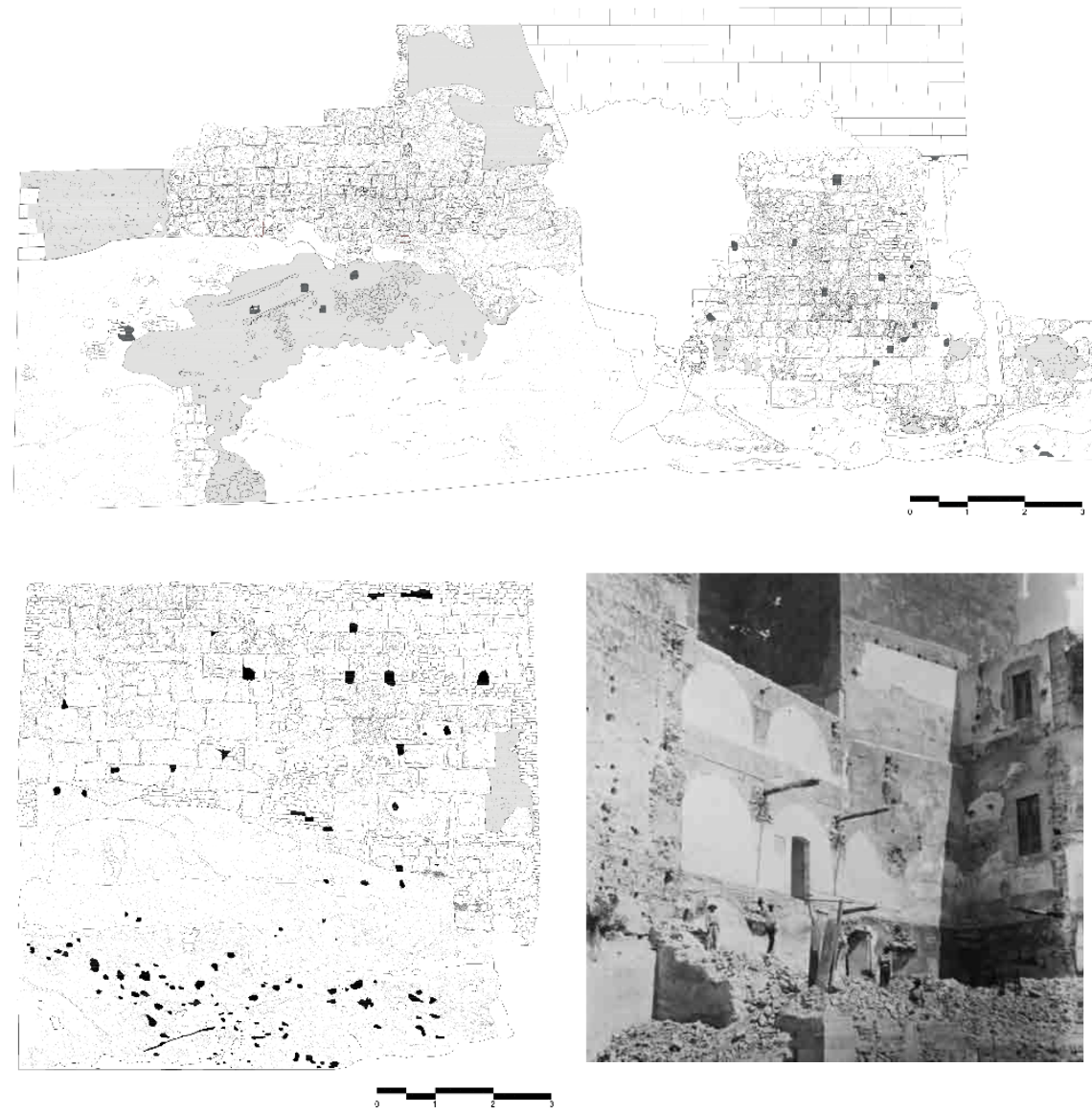

Figure 6: Graphic restitution of the wall face with the traces of the prisons demolished in 1902 following the project of the Regional Office for the Preservation of Monuments; (ph. Archive of the BAPSAE Superintendency of Cagliari and Oristano). 


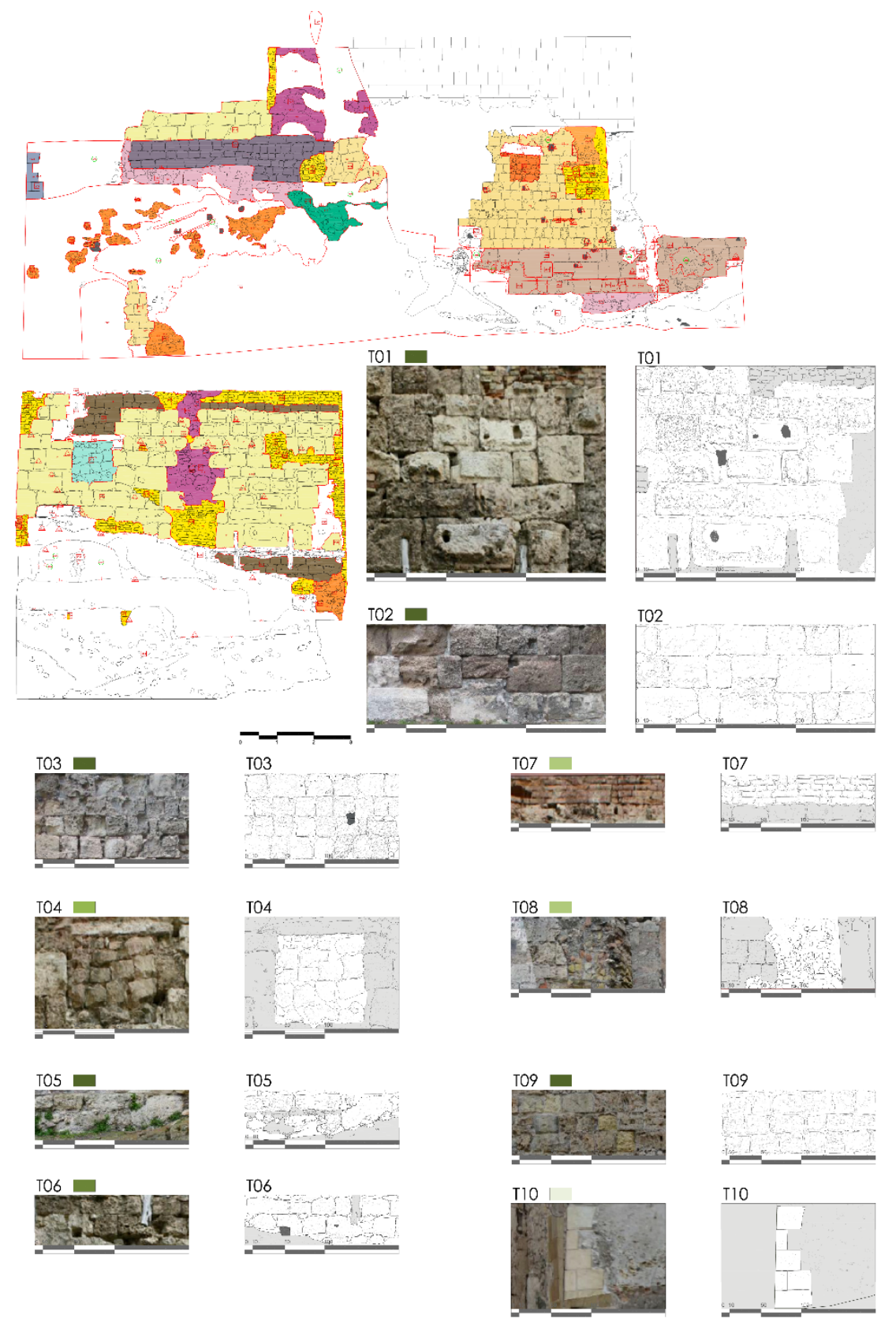

Figure 7: Identification of stratigraphic units and mapping of wall types. 

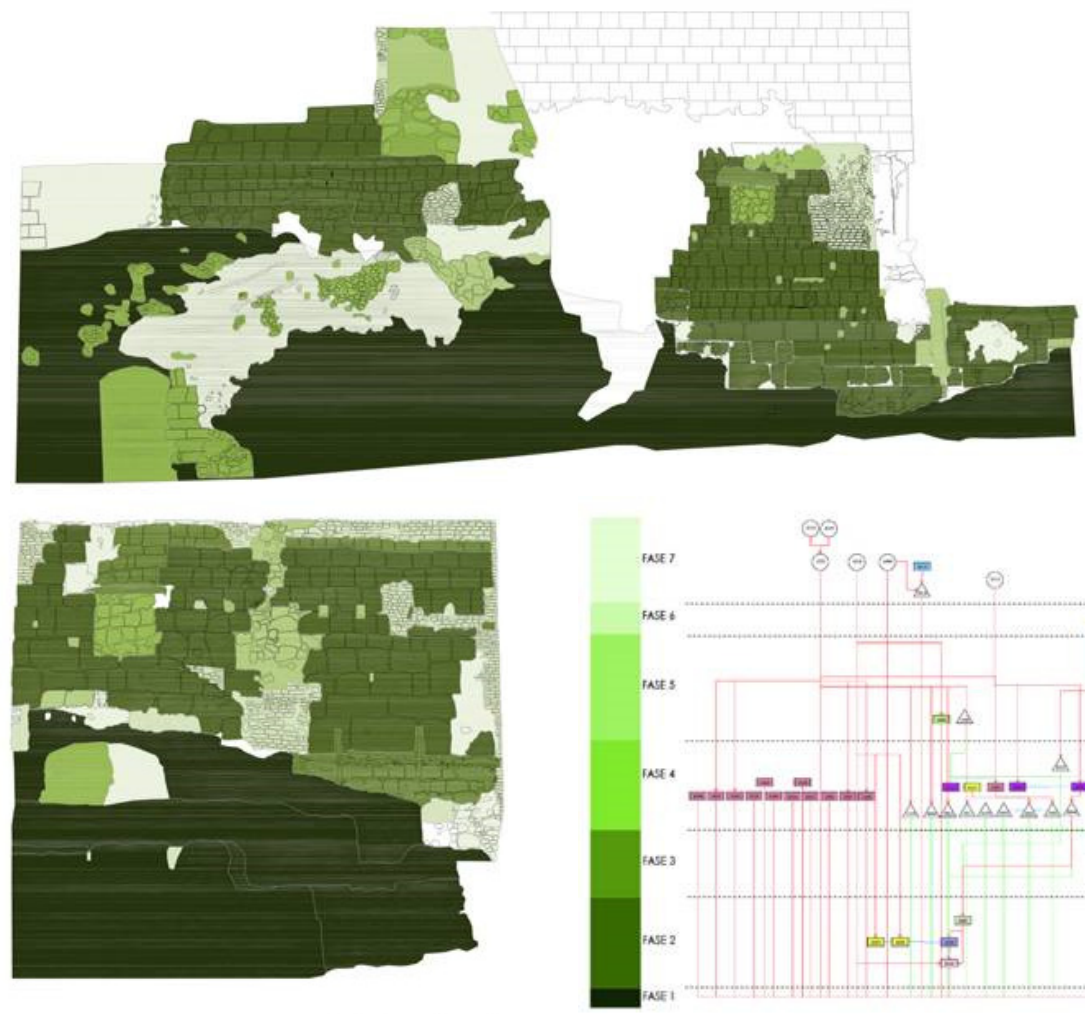

Figure 8: Chronological construction sequence and Harris matrix (portion).

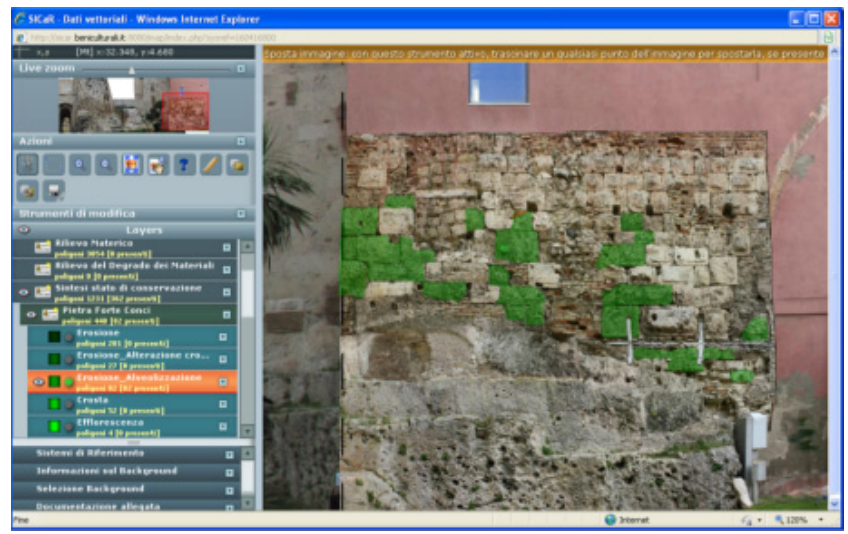

Figure 9: Mapping of single ashlars on the photogrammetric survey in the $\mathrm{SICaR} /$ web system. 


\section{Conclusion}

The research provides a substantial contribution to the definition of a methodology for the study of the growth and transformation of walled cities, by means of an archaeological approach. Even if currently in progress, the study carried out on the area of St. Pancrazio in Cagliari allows to state that the proposed process can be effectively adopted in order to date urban palimpsests and proves the centrality of the study of defensive system in order to understand the evolution of the historical city as a whole.

The extent of the outlined research involves multidisciplinary contribution and the implementation of the described multi-access information system. This virtuous analysis, documentation and interpretation process represents an essential working tool for whoever operates in the stratified urban context. Only by this deep knowledge of the stratified essence of our ancient cities, it could be possible to monitor and design urban transformations according to a process of a neverending stratification aware and respectful of what is pre-existing.

\section{References}

[1] Cadinu, M., Urbanistica medioevale in Sardegna, Bonsignori:Roma, 2001.

[2] Pirinu, A., Il disegno dei baluardi cinquecenteschi nell'opera dei fratelli Paleari Fratino, All'Insegna del Giglio, Documenti di archeologia postmedievale: Firenze, 2013.

[3] Gazzola, P., Cecchini L., La Cittadella Museale della Sardegna, Università di Cagliari: Cagliari, pp. 84-85, 1981.

[4] Cadinu, M., I catasti e la storia dei luoghi, Annuario nazionale di storia della città e del territorio, ed. Kappa:Roma, 2013.

[5] Fiorino, D.R., La stratigrafia urbana. Proposte per Stampace. Idee per un piano di conservazione del quartiere storico cagliaritano, ed. Gangemi: Roma, pp. 69-74, 2009.

[6] Fiorino, D.R., Le architetture religiose del barocco in Sardegna. Modelli colti e creatività popolare dal XVI al XVIII secolo, AIPSA: Cagliari, pp. 159-163, 2002.

[7] Mattana, M., Schirru, G., Le fortificazioni pisane del "Castello" di Cagliari: conoscenza e progetto di conservazione e valorizzazione, Quaderni della Soprintendenza archeologica per le province di Cagliari e Oristano, 20, pp. 137-178, 2003.

[8] Giammusso, F.M., Personal communication La ricostruzione virtuale di architetture perdute e non finite: il tempio $G$ di Selinunte, la chiesa di San Domenico a Cagliari e il palazzo Moncada di Caltanissetta, 23 May 2014, Cicles of conferences: Storie e protagonisti di luoghi scomparsi, Archivio storico Search, Cagliari.

[9] Fiorino, D.R., Laboratory of Restoration, Specialistic Degree in Architecture, University of Cagliari, AA. 2013/2014. 